\title{
MENCIPTAKAN PEMBELAJARAN MENYENANGKAN MELALUI OPTIMALISASI JEDA STRATEGIS DENGAN KARIKATUR HUMOR DALAM BELAJAR MATEMATIKA*
}

Oleh: Darmansyah, ST., M.Pd.dkk. **

\section{Abstrak}

Rendahnya motivasi belajar, kurang kreatif, cepat bosan, sering jenuh, tegang saat mengikuti pelajaran, meningkatnya jumlah siswa keluar kelas, tingginya persentase siswa yang tidak menyelesaikan pekerjaan rumah merupakan persoalan pelik yang sering muncul dalam pembelajaran Matematika di SMAN 7 Padang. Hal ini selain disebabkan karakteristik Matematika yang abstrak, berhirarkhi dan sulit dipahami, juga akibat strategi mengajar yang diterapkan guru cenderung monoton, kurang menyenangkan dan membosankan bagi siswa, sehingga pembelajaran menjadi tidak efektif dan berdampak rendahnya capaian hasil belajar. Penelitian tindakan kelas yang menerapkan strategi pembelajaran menyenangkan melalui optimalisasi jeda strategis menggunakan karikatur humor ini merupakan upaya untuk mengatasi sebagian masalah tersebut.

Prosedur penelitian adalah dengan memberikan istirahat sejenak yang disebut jeda strategis selama 2-3 menit setiap periode waktu 30 menit pembelajaran. Saat jeda strategis berlangsung, guru menyisipkan gambar karikatur humor menggunakan trasparansi, sehingga dapat memancing siswa ketawa. Karikatur humor yang digunakan sebagai instrumen

*) Tulisan ini berupa Hasil Penelitian PTK terbaik tingkat Nasional tahun 2007

**) Drs.Darmansyah, ST. M.Pd. adalah dosen Teknologi Pendidikan FIP Universitas Negeri Padang; Azwarman, S.Pd. \& Erdawati, S.Pd.guru SMAN 7 Padang-anggota peneliti 
perlakuan didisain dan diadopsi dari berbagai sumber yang kemudian diseleksi melalui uji coba. Data mengenai reaksi siswa dikumpulkan melalui catatan pengamatan oleh kolaborator kemudian diperkuat dengan penyebaran angket kepada siswa dan data hasil belajar diperoleh melalui tes. Teknik analisis data menggunakan perhitungan "mean score". Hasil penelitian ini mengungkapkan bahwa penayangan gambar karikatur humor dapat memancing siswa untuk ketawa secara bersama-sama di dalam kelas. Dari hasil analisis observasi reaksi siswa saat jeda strategis, $83.94 \%$ siswa ketawa. Analisis angket mengungkapkan 86,33\% siswa dapat tertawa dan menyatakan pembelajaran dengan penayangan karikatur humor dalam jeda strategis sangat menyenangkan. Hasil belajar siswa menunjukkan angka rata-rata 71,89 yang relatif lebih tinggi daripada capaian hasil belajar sebelumnya. Dengan demikian optimalisasi jeda strategis melalui sisipan karikatur humor dapat menciptakan Pembelajaran menyenangkan dan berdampak positif terhadap peningkatan capaian hasil belajar.. Hasil penelitian ini diharapkan dapat menjadi bahan masukan bagi para guru dan peneliti lain dalam melaksanakan tugas pembelajaran maupun dalam penelitian lanjutan.

Kata Kunci: Pembelajaran Menyenangkan, Jeda Strategis, Karikatur Humor

\section{PENDAHULUAN}

Hasil pengamatan beberapa guru Matematika di SMA Negeri 7 Padang menunjukkan bahwa sebagian besar siswa kurang bergairah dalam mengikuti pembelajaran. Indikasi menurunnya gairah belajar tersebut dapat dilihat dari kurangnya kreatifitas siswa, motivasi belajar rendah, meningkatnya jumlah siswa keluar kelas saat pembelajaran berlangsung dan tingginya persentase siswa yang tidak mengerjakan pekerjaan rumah. Pada gilirannya kondisi ini akan mempengaruhi efektifitas pembelajaran. Di antara 
beberapa kelas yang diamati ternyata kelas $\mathrm{IX}_{3}$ termasuk yang paling rendah hasil belajarnya.

Penelitian Herman Nirwana (2003:4) mendukung sinyalemen di atas dengan menyatakan bahwa banyak siswa meninggalkan pelajaran matematika di beberapa SMA di Sumatera Barat sebelum pelajaran selesai. Di antara empat mata pelajaran yang dianalisis (fisika, kimia, bahasa Inggris dan matematika), ternyata mata pelajaran matematika menempati urutan paling banyak siswa yang absen dan siswa yang meninggalkan kelas sebelum pelajaran selesai. Hal ini menurut Herman mengindikasikan bahwa mata pelajaran matematika termasuk salah satu mata pelajaran yang kurang disukai siswa dan membosankan.

Jika dilihat dari NEM rata-rata SMA di Sumatera Barat, ternyata mata pelajaran matematika lebih rendah dibandingkan dengan mata pelajaran lainnya. NEM rata-rata pelajaran matematika SMA di Sumbar 4,50. Angka tersebut paling rendah dibandingkan dengan PPKN $(5,54)$, IPS $(5,65)$, IPA $(5,62)$, Bahasa Indonesia $(6,36)$, Bahasa Inggeris $(4,91)$. Artinya NEM matematika berada di bawah rata-rata mata pelajaran lainnya. NEM pada tahun 2002/2003 sebesar 3,92 , berarti turun dari sebelumnya yang menempatkan Sumatera Barat pada peringkat ke 19 di antara 30 provinsi di Indonesia. (Diknas Sumbar: 2004).

Ketidakberhasilan pembelajaran dapat dilihat dari beberapa indikasi baik dari proses maupun capaian hasil belajarnya. Dari segi proses pembelajaran dapat diamati misalnya bagaimana siswa dapat menikmati pembelajaran sebagai suatu kegiatan yang menyenangkan. Artinya jika suatu pembelajaran tidak berhasil membangkitkan minat dan motivasi siswa untuk belajar secara menyenangkan, maka pembelajaran itu tidak dapat dikatakan efektif.

Keberhasilan pembelajaran pada hakekatnya ditentukan oleh banyak faktor. Rendahnya hasil belajar matematika siswa juga 
dipengaruhi berbagai komponen yang ada dalam sistem pembelajaran. Dalam teori pemrosesan informasi, komponen siswa sebagai penerima pesan dan guru yang beperan sebagai sumber penyampai pesan menjadi faktor penentu keberhasilan pembelajaran. Namun di antara keduanya, komponen guru dianggap faktor penyebab paling berpengaruh terhadap ketidakberhasilan belajar siswa. Di sinilah pentingnya kemampuan berbagai kompetensi yang diperlukan untuk mendukung keberhasilannya dalam melaksanakan pembelajaran.

Satu di antara beberapa kompetensi yang sering diabaikan guru adalah kemampuan merancang dan menerapkan strategi yang tepat dalam pembelajaran. Banyak guru yang tidak mampu mengorkestrasi berbagai potensi dan lingkungannya, sehingga pembelajaran menjadi tidak efektif. Strategi pembelajaran yang diterapkan sering menimbulkan kebosanan dalam belajar, sehingga peserta didik tidak dapat menikmati pembelajaran dengan motivasi tinggi. Padahal menurut Dryden \& Vos, (2000:213), semangat belajar muncul ketika suasana begitu menyenangkan dan belajar akan efektif bila siswa dalam keadaan gembira.

Kesenangan belajar sangat erat kaitannya dengan cara ketiga jenis otak memproses informasi yaitu otak reptil, otak mamalia dan otak neo-cortex. Apabila seseorang dalam keadaan bahagia, tenang dan rileks, maka otak neo-cortex dapat aktif digunakan untuk berpikir dan merupakan $80 \%$ dari otak manusia. Otak reptil bekerja ketika seseorang dalam keadaan tegang, stres, takut, sehingga pikirannya dapat menjadi kosong, tidak mengingat apaapa yang dipelajari sebelumnya. Karena itu, Pembelajaran menyenangkan merupakan upaya yang harus terus-menerus dilakukan oleh guru dalam pembelajaran.

Untuk menciptakan suasana menyenangkan dalam pembelajaran, guru dapat merancang dan menerapkan berbagai strategi. Komunikasi dan interaksi guru dengan peserta didik yang terbuka dan penuh keriangan dapat menciptakan Pembelajaran yang 
menyenangkan. Lingkungan fisik belajar yang kondusif memungkinkan siswa dapat bereaksi dan berkreasi dengan penuh motivasi. Penataan suasana hati dengan musik dapat meningkatkan kegairahan belajar.

Salah satu strategi yang mendapatkan perhatian para ahli adalah strategi pembelajaran menyenangkan melalui pemanfaatan "Jeda Strategis" secara optimal. Jeda strategis adalah istirahat sejenak dari kegiatan belajar dan mengisinya dengan kegiatan menyenangkan, setelah menjalani aktifitas belajar selama 20-25 menit. Memberikan kegembiraan kepada siswa di saat mengalami penurunan konsentrasi dalam belajar melalui jeda strategis yang menyenangkan tersebut dapat menggairahkan, sehingga siswa akan mengalami penyegaran, berkonsentrasi kembali dan dapat mengikuti pembelajaran dengan penuh motivasi.

Mengikuti pembelajaran dengan suasana menyenangkan akan mengaktifkan otak neo-cortex, sehingga dapat memberikan kemampuan optimal dalam memecahkan beberbagai persoalan pembelajaran. Suasana menyenangkan dalam pembelajaran juga sekaligus dapat menstimulus otak mamalia (disebut juga otak memori) yang dapat memberikan kemampuan kepada siswa untuk mengingat dalam waktu lama dan dapat dipanggil kembali saat informasi diperlukan dalam ujian. Berarti optimalilasi jeda strategis menggunakan karikatur humor ini akan dapat menciptakan suasana menyenangkan dalam belajar dan pada gilirannya akan meningkatkan hasil belajar.

Apakah optimalisasi jeda strategis dengan karikatur humor akan menciptakan suasana menyenangkan dan meningkatkan hasil belajar matematika siswa di SMA Negeri 7 Padang? Pertanyaan inilah yang dijawab dalam penelitian ini. Penelitian ini juga menjawab pertanyaan apakah strategi pembelajaran menyenangkan dapat meningkatkan hasil belajar Matematika siswa. 
Hasil penelitian ini diharapkan bermanfaat bagi siswa dan guru dalam mengatasi berbagai kendala belajar seperti kejenuhan, ketidakmenarikan pelajaran, sehingga pada gilirannya dapat meningkatkan hasil belajarnya. Dosen berpeluang memanfaatkan berbagai sumber untuk menciptakan strategi pembelajaran yang menyenangkan. Tenaga kependidikan lainnya dapat menciptakan strategi pembelajaran menyenangkan untuk diterapkan pada bidang pendidikan lainnya.

\section{KAJIAN PUSTAKA}

\section{A. Kerangka Teoretis}

Strategi pembelajaran menyenangkan merupakan strategi pengorgnisasian pemberian pembelajaran, penyajian bahan ajar, penggunaann media pengajaran, pengelolaan jadwal dan pengalokasian pengajaran yang diorganisasikan.

Seiring dengan dengan pendapat tersebut DePorter, Reardon dan Singer (1999) menjelaskan bahwa strategi pembelajaran menyenangkan itu adalah kemampuan untuk mengubah komunitas belajar menjadi tempat yang meningkatkan kesadaran, daya dengar, partisipasi, umpan balik, dan pertumbuhan, di mana emosi dihargai. Di lingkungan seperti inilah siswa dapat beranjak ke keadaan prima, mau bertanggung jawab, saling mempercayai, dan tempat yang tanpa batas untuk mencapai apapun. Lebih lanjut DePorter, dkk. mengungkapkan bahwa bila guru mampu merancang strategi yang tepat dan menyenangkan, maka ruang kelas dapat menjadi "rumah" tempat siswa tidak hanya terbuka terhadap umpan balik, tetapi juga menjadi tempat mereka belajar, mengakui dan mendukung orang lain, tempat mereka mengalami kegembiraan dan kepuasan, memberi dan menerima, belajar dan tumbuh. Inilah yang diistilahkan sebagai konteks menata panggung belajar. 
DePorter, Reardon dan Singer (1999:78) menggambarkan salah satu strategi pembelajaran menyenangkan dengan menata suasana kelas adalah optimalisasi pada saat jeda strategis. Cara terbaik untuk mengoptimalkan jeda strategis adalah membuat kuis, pertanyaan lucu, humor, menayangkan gambar karikatur yang mengandung humor.

\section{Kaitan Pemrosesan Informasi, Fungsi Otak dan Strategi Pembelajaran}

Pemrosesan dan penyimpanan informasi terjadi antara stimulus dengan respons. Travers (1982) menyatakan bahwa sistem otak yang kompleks antara stimulus dan respons tersebut harus ditembus, sehingga otak dapat secara aktif mencari, memilih, menyusun, dan pada saat yang diperlukan memanggil kembali serta memanfaatkan informasi.

Kurfiss (1981) sependapat dengan para ahli psikologi terdahulu yang menyatakan bahwa stimulus eksternal itu dapat menjadi motivator yang aktif, bila stimulus itu bermakna bagi siswa melalui pembentukan hubungan dengan keadaan internal siswa. Oleh karena itu, stimulus yang diberikan guru dari lingkungan belajar akan memberikan pengaruh yang berarti terhadap peningkatan motivasi belajar siswa.

Berkaitan dengan otak dan stimulus lingkungan tersebut, Shapiro (1997) menyatakan ada tiga jenis otak yang berfungsi sebgai pemroses informasi yaitu; (1) Otak neocortex , (2) otak mamalia, dan (3) otak reptil. Otak neocortex akan memproses informasi (secara normal dan kreatif) jika menerima stimulus dari lingkungan yang menyenangkan. Bekerjanya otak neo-cortex inilah yang memberikan banyak kontribusi terhadap keberhasilan dan keefektifan belajar. Strategi pembelajaran terbaik memungsikan otak neo-cortex dalam berpikir dan belajar 
adalah dengan memberikan rangsangan yang nyaman dan menyenangkan.

Belajar dan menyimpan informasi dalam pola-pola asosiasi yang kuat merupakan langkah pertama menuju pengembangan kemampuan otak yang belum termanfaatkan. "Ini adalah salah satu kunci memperbaiki daya ingat Anda: mengasosiasikannya dengan sebuah citra yang kuat dan menggunakan satu atau lebih kemampuan otak Anda (Vos:2000:120)". Metode asosiasi manapun yang digunakan, buatlah yang aneh, lucu dan emosional, karena 'filter' otak yang meneruskan informasi ke memori jangka panjang berhubungan erat dengan emosi. Dan hubungkan asosiasi dengan sebanyak mungkin indra. penglihatan, pendengaran, pembau, perasa, dan pengecap" (Vos, 2000:124).

Otak menurut Shapiro (1997) memiliki sebuah senyawa kimia yang disebut neotransmitter dapat membentuk reaksi-reaksi emosi kita dengan cara menyampaikan pesan emosi dari otak ke berbagai bagian tubuh. Serotonin berperan secara signifikan membantu menangani stres dalam pengobatan depresi, gangguan kompulsif obsesif dan gangguan kejiwaan lainnya. Otak kita dapat dilatih untuk memproduksi serotonin secara alami dan sederhana, seperti pola makan yang sehat, tidur yang cukup, olah raga dan tersenyum atau ketawa. Lebih Ianjut Shapiro menyatakan, ketika kita tersenyum otot-otot wajah berkontraksi, mengurangi aliran darah ke pembuluh darah terdekat. Ini membuat darah menjadi dingin, menurunkan temperatur batang otak, dan memicu produksi serotonin. Inilah yang membuat terpicunya otak neo-cortex bekerja secara optimal.

Apabila peserta didik mendapat rangsangan yang wajar 
dan menyenangkan, merasa aman dan nyaman secara fisik dan emosional dalam belajar, maka semua kecerdasan tertinggi yang dimilikinya akan berfungsi secara optimal. Berfungsinya seluruh kecerdasan ini akan meningkatkan efektifitas pembelajaran.

\section{Daya Ingat dan Jeda Strategis}

DePorter dan Hernacki (1999) menyatakan bahwa kita mengingat dengan sangat baik informasi yang diterima pada awal dan akhir sesi belajar. Selama 90 menit pembelajaran sebaiknya dibagi dalam dua kali jeda setiap 30 menit. Di saat jeda tersebut siswa dapat ditingkatkan kesegaran konsentrasi belajar dan daya ingatnya melalui kegiatan-kegiatan yang menyentuh emosi, seperti selingan musik, cerita-cerita lucu, humor dan lain-lain. "Jika Anda secara sadar menciptakan kesempatan untuk membawa kegembiraaan ke dalam pekerjaan Anda, kegiatan belajar dan mengajar akan lebih menyenangkan. Kegembiran yang tercipta melalui jeda menyenangkan membuat siswa siap belajar lebih mudah dan bahkan dapat mengubah sikap negatif" (DePorter dan Hernacki, 1999:216).

Cooper dan Sawaf (1999) menyatakan bahwa jika kita bekerja dan belajar terlalu lama pada kegiatan-kegiatan yang memeras otak, waktu yang dibutuhkan untuk memecahkan masalah meningkat hinggga 500 persen (lima kali lipat). Oleh karena itu, kita membutuhkan istirahat yang disebut "jeda strategis". Lebih lanjut Cooper dan Sawaf (1999) menjelaskan bahwa jeda strategis tersebut adalah istirahat singkat secara sadar dari pekerjaan setiap 20 hingga 30 menit untuk menyempatkan diri mengubah pusat perhatian,mengubah fokus pandangan, mengendurkan otot-otot leher dan pundak dan menyisihkan waktu sejenak untuk mengobrol hal yang ringan-ringan namun kreatif dan menyenangkan. 
Sejalan dengan pendapat tersebut Shapiro (1997) menganjurkan untuk mendorong siswa pada saat yang tepat, diutamakan pada saat jeda strategis menciptakan kegembiraan. Salah satu keterampilan sosial yang sangat berharga yang mengindikasikan kecerdasan emosional tinggi dan menyenangkan adalah humor. Karena itu menggunakan humor dalam pembelajaran merupakan pilihan yang bijaksana.

Daya ingat dalam belajar juga dipengaruhi oleh strategi yang diterapkan. Pengaturan irama dan waktu termasuk penyisipan karikatur yang afirmatif dalam jeda strategis memberikan dampak yang baik dalam pembelajaran. Dapat diartikan bahwa mengisi waktu jeda strategis dengan karikatur humor akan dapat meningkatkan daya ingat dan afirmasi siswa dalam belajar. Secara grafis daya ingat dalam belajar dapat dijelaskan dalam Gambar 1 .

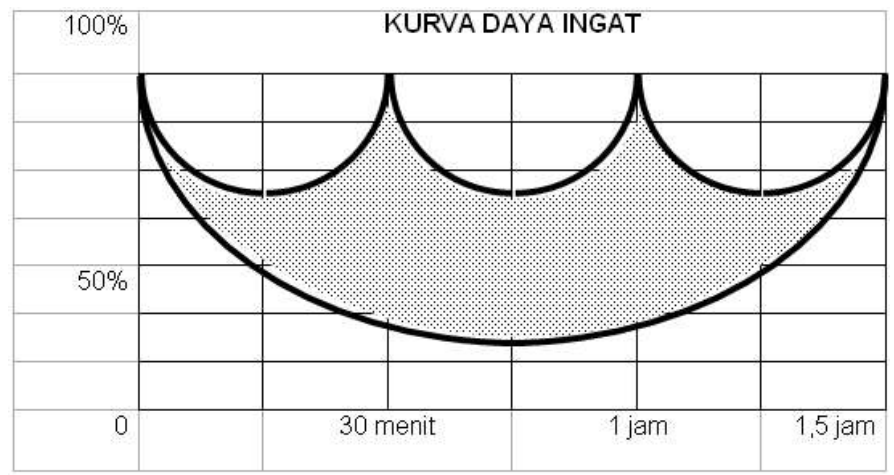

Catatan: Kurva Daya Ingat diadobsi dari Bobbi DePorter dan Mike Hernacki (1999) dalam buku Quantum Learning dan digambar ulang Darmansyah, 2005) .

\section{Humor dalam Pembelajaran}

Teknik menggunakan humor dalam memeriahkan 
pembelajaran merupakan tradisi kuno Babylonian Talmud, yaitu dari seorang guru Talmudic yang hidup sekitar 1700 tahun yang lalu dan kemudian menjadi tradisi bagi guru lainnya. Guru-guru tersebut memulai pembelajaran dengan sesuatu yang bersifat humoris, mereka tertawa bersama, dan setelah itu baru memulai pembelajaran. Rabbi Meir, guru Talmudic lainnya yang ahli dalam dongeng menjalankan pembelajaran dengan banyak perumpaan, menggunakan humor sebagai selingan dalam pembelajaran. Para guru tersebut sangat yakin akan nilai positif humor dalam pendidikan, bahkan pembelajaran etika dan agama sekali pun.

Humor dapat menghindarkan seseorang dari rasa bosan yang berlebihan. Cooper dan Sawaf (1999) menyatakan bahwa humor seorang guru mendorong anak-anak untuk selalu ceria dan gembira serta tidak akan lekas merasa bosan atau lelah. Pendapat yang sama juga dinyatakan Staton (1978) bahwa kecakapan mempergunakan kesempatan yang tepat untuk menyisipkan humor secara bijaksana sepanjang pemberian pelajaran, akan mendorong siswa untuk tidak bosan-bosannya mengikuti pelajaran tersebut. Oleh karena itu kata Staton, ketika suasana kebosanan sudah mulai tampak di dalam kelas, hendaknya guru segera berupaya mengembalikannya ke suasana yang menyenangkan dan rileks. Strategi yang dianggap ampuh untuk mengembalikan suasana tenang adalah dengan selingan cerita lucu dan karikatur humor.

Alasan menggunakan humor menurut Shor dan Freire (2001), adalah karena subjektivitas sangat melekat dengan humor dan perasaan, baik yang disajikan lewat idiom kritis maupun ungkapan santun. Humor membantu momen belajar menjadi "nyata" dan ini merupakan sebuah kualitas yang mampu membalik pengalaman sekolah buatan 
(artifisial). Ditambahkan Shor dan Freire, siswa umumnya senang berhubungan dengan guru yang menghibur (yang mampu membanyol untuk menarik perhatian). Selain itu siswa juga harus membangun humor dari dirinya sendiri dalam memahami bahan ajar yang dipelajarinya.

Pentingnya humor juga dikemukakan Brotherton (1996) yang memberikan alasan bahwa menggunakan humor di ruang kelas berdampak sangat baik terhadap pikiran positif siswa. Dampak tersebut termasuk faktor komunikasi dan efek kemanusiaan dari humor pada citra seseorang. Pendapat tersebut didukung Berk (1998) yang menyatakan bahwa humor memiliki kemampuan untuk mengurangi kegelisahan siswa, meningkatkan kemampuan belajar, dan meningkatkan kepercayan diri. Humor juga dapat lebih mendorong siswa untuk menciptakan Pembelajaran menyenangkan dan sangat bermanfaat digunakan di ruang kelas.

Banyak manfaat yang dapat dipetik dari penggunaan humor di dalam kelas. Flowers (1995) menyatakan bahwa ada keuntungan yang signifikan untuk menggunakan humor di ruang kelas. Manfaat humor mencakup mengurangi "stress", meningkatkan motivasi, mengurangi jarak secara psikologis antara guru- siswa, dan meningkatkan kreatifitas.

Dari pendapat di atas sekurang-kurangnya ada empat manfaat humor dalam pembelajaran yaitu: (1) membangun hubungan dan meningkatkan komunikasi antara guru dan peserta didik, (2) mengurangi "stress, (3) membuat pembelajaran menjadi menarik, (4) meningkatkan daya ingat suatu materi pelajaran.

Pendapat di atas juga diperkuat Hershey $\mathrm{H}$. Friedman, Linda W. Friedman (2002) dalam penelitian yang berjudul 
Using Humor in the Introductory Statistics Course, mengungkapkan bahwa penggunaan humor dalam pembelajaran statistik telah meningkatkan hasil belajar secara signifikan. Darmansyah (2002) dalam penelitian tentang persepsi siswa tentang sisipan humor dan hubungannya dengan hasil belajar. Hasil penelitiannya mengungkapkan bahwa persepsi tetang sisipan humor siswa memiliki hubungan yang signifikan dengan hasil belajar siswa. Bryant, J., Comiky, P.W., and Crane, J.S. (1980) 'Relationship Between College Teachers' Use of Humor in Classroom and Student' Evaluations of Their Teacher" yang mengungkapkan bahwa ada hubungan positif dan signifikan antara penggunaan humor di dalam kelas dengan hasil evaluasi terhadap siswanya.

\section{PELAKSANAAN PENELITIAN}

A. Deskripsi Lokasi,Waktu, Mata Pelajaran dan Karakteristik Siswa

Penelitian ini dilaksanakan di SMA Negeri 7 Padang. Pelaksanaan penelitian mulai dari bulan April sampai dengan November 2006. Pelajaran yang menjadi objek penelitian adalah mata pelajaran Matematika dengan subjek siswa kelas I, semester 1 SMA Negeri 7 Padang tahun ajaran 2006-2007.

\section{B. Rancangan Penelitian}

\section{Perencanaan Penelitian}

Karikatur humor dirancang sebanyak 50 lembar untuk digunakan dalam optimalisasi jeda strategis. Setelah diperhitungkan untuk kebutuhan dua kali pelaksanaan tindakan, maka kebutuhan karikatur dipilih 20 lembar karikatur humor. Ujicoba instrumen dilaksanakan untuk memilih 20 karikatur terbaik dari 50 lembar karikatur yang telah dirancang. Pelaksanaan ujicoba dilakukan pada minggu ketiga bulan Juli 2006 dengan memberikan 50 gambar karikatur kepada siswa, kemudian siswa diminta untuk memberikan penilaian. 


\section{Pelaksanaan Penelitian}

Pelaksanaan tindakan dalam kelas disesuaikan dengan siklus yang telah direncanakan.

\section{Siklus 1}

a. Menjelaskan optimalisasi jeda strategis dengan karikatur humor

b. Melaksanakan pembelajaran dengan jadwal seperti biasa

c. Setelah pembelajaran berjalan selama 25 menit, guru melaksanakan jeda strategis

d. Tayangkan gambar karikatur humor sesuai dengan topik yang sedang dibahas menggunakan transparansi dan.

e. Guru memberikan komentar dan mengamati reaksi siswa

f. Guru yang bertindak sebagai kolaborator mencatat seberapa jauh kegembiraan yang terjadi secara kualitatif dan berapa jumlah siswa yang menikmati pembelajaran menyenangkan saat jeda strategis.

g. Setelah jeda strategis dilaksanakan 2-3 menit, guru kembali melanjutkan pembelajaran

h. Jeda strategis berikutnya kembali dilaksanakan selama 2-3 menit dengan menayangkan gambar karikatur humor.

i. Setelah menayangkan gambar tersebut, guru memberikan komentar dan meminta tanggapan siswa tentang penayangan gambar tersebut.

j. Melaksanakan jeda strategis berikutnya dengan interval waktu yang sama, sampai pembelajaran berakhir.

k. Melakukan evaluasi tentang penggunaan karikatur humor pada topik tersebut dengan mengajukan pertanyaan kepada si swa.

I. Memberikan pertanyaan menggunakan angket tentang optimalisasi jeda strategis dan penggunaan instrumen 
serta saran siswa secara keseluruhan pada siklus pertama

m. Melakukan analisis terhadap angket dan saran siswa.

n. Memberikan tes tentang materi pelajaran yang telah diberikan selama periode siklus pertama.

o. Melakukan analisis terhadap tes hasil belajar pada siklus pertama

p. Melakukan evaluasi terhadap hasil yang telah dicapai dan merencanakan tindakan berikutnya.

\section{Observasi dan Alat Pengumpul Data}

Pelaksanaan observasi menggunakan beberapa macam alat pengumpul data sebagai berikut. Angket digunakan untuk mendapatkan informasi apakah optimalisasi jeda strategis dapat menciptakan pembelajaran menyenangkan. Tes hasil belajar digunakan untuk mendapatkan data hasil belajar pada setiap siklus.

\section{Teknik Analisis Data}

Hasil observasi dianalisis dengan metode analisis deskriptif komparatif. Analisis angket dilakukan dengan membuat kriteria berdasarkan skor yang diperoleh siswa dan digambarkan dalam bentuk tabulasi. Hasil belajar dianalisis dengan metode statistik deskriptif untuk melihat keberhasilan siswa dalam pembelajaran. Sedangkan perbedaan hasil belajar dianalisis dengan teknik perbedaan mean score.

\section{Evaluasi dan Refleksi}

Evaluasi terhadap capaian yang diperoleh pada siklus 1 didasarkan pada dua hal yaitu tingkat kesenangan belajar dan hasil belajar. Apabila jumlah siswa yang menikmati pembelajaran menyenangkan kurang dari $80 \%$ dan ratarata hasil belajar kurang dari 7,00, maka tindakan dilajutkan ke siklus 2. Selanjutnya menentukan cara meningkatkan kesenangan belajar sebagai dasar perbaikan pada tindakan 
yang akan dilakukan pada siklus 2 .

\section{Siklus 2}

Pelaksanaan siklus 2 polanya sama dengan siklus 1 , setelah dilakukan perbaikan dan penyempurnaan sesuai hasil evaluasi sebelumnya. Perbaikan dan penyempurnaan ini menyangkut kebijakan pelaksanaan tindakan yang diambil dengan mempertimbangkan berbagai kelemahan yang ditemukan pada siklus 2 .

\section{HASIL PENELITIAN DAN PEMBAHASAN}

\section{A. Hasil Penelitian}

\section{Data dan Analisis Data Siklus 1 dan Siklus 2}

a. Hasil Observasi Reaksi Siswa

Data yang ditampilkan berikut ini adalah hasil observasi pada siklus 1 dan siklus 2 yang diambil angka rata-rata dari pertemuan pertama dan kedua tentang reaksi siswa setelah penayangan gambar karikatur humor. Observasi ini dilakukan untuk mengetahui apakah siswa ketawa setelah gambar karikatur humor ditayangkan dengan transparansi. Rangkuman hasil observasi secara lengkap dapat dilihat dalam Tabel 1 berikut:

Tabel 1. Rangkuman Hasil Observasi Reaksi Siswa Setelah Dilakukan Tindakan Siklus 1 dan Siklus 2

\begin{tabular}{|c|l|c|c|c|c|}
\hline \multirow{2}{*}{ No } & \multicolumn{4}{|c|}{ Reaksi Siswa } \\
\cline { 3 - 6 } & \multirow{2}{*}{ Pertemuan } & \multicolumn{2}{|c|}{ Siklus 1 } & \multicolumn{2}{c|}{ Siklus 2 } \\
\cline { 3 - 6 } & $\begin{array}{c}\text { Ketawa } \\
(\%)\end{array}$ & $\begin{array}{c}\text { Tidak } \\
\text { Ketawa } \\
(\%)\end{array}$ & $\begin{array}{c}\text { Ketawa } \\
(\%)\end{array}$ & $\begin{array}{c}\text { Tidak } \\
\text { Ketawa } \\
(\%)\end{array}$ \\
\hline \multirow{4}{*}{1} & Pertama & 77.23 & 22.77 & 84.83 & 15.17 \\
\cline { 2 - 6 } & Kedua & 77.96 & 22.04 & 84.93 & 15.07 \\
\cline { 2 - 6 } & Ketiga & 77,08 & 22,92 & 83,33 & 16,67 \\
\cline { 2 - 6 } & Keempat & 78,13 & 21,88 & 86,46 & 13,54 \\
\hline \multicolumn{2}{|c|}{ Rata -rata } & 77.60 & 22.40 & 84.90 & 15.11 \\
\hline
\end{tabular}


Berdasarkan hasil observasi terhadap reaksi siswa setelah pelaksanaan tindakan siklus 1 pertemuan pertama dan kedua, diperoleh angka rata-rata $77.60 \%$ siswa ketawa dan $22.40 \%$ tidak ketawa. Angka ratarata yang diperoleh pada siklus 1 , ternyata belum mencapai indikator kinerja yang telah direncanakan sebelumnya yaitu $80 \%$ Oleh karena itu, tindakan perlu dilanjutkan dengan siklus 2 .

Setelah tindakan dilanjutkan pada siklus 2 dan dilakukan observasi, didapatkan angka rata- rata $84,90 \%$ siswa ketawa dan $16.10 \%$ tidak ketawa. Berarti perbaikan yang dilakukan pada siklus 2 mampu meningkatkan persentase siswa yang ketawa sebesar $7,30 \%$. Angka tersebut telah dapat mencapai indikator kinerja yang ditetapkan sebelumnya yaitu $80 \%$. Berarti tindakan tidak perlu dilanjutkan.

b. Hasil Angket

Pertanyaan pertama tentang tingkat kelucuan karikatur $75.80 \%$ siswa menjawab bahwa karikatur tersebut lucu. Sebanyak $75.78 \%$ siswa menyatakan karikatur yang ditayangkan mampu membuat mereka ketawa. Selanjutnya sebesar $77.90 \%$ siswa berpendapat tayangan karikatur humor dalam jeda strategis dapat menciptakan suasana menyenangkan dalam pembelajaran.

Kemudian tentang komentar guru dalam kelas, $75.80 \%$ siswa menyatakan dapat membuat mereka senang belajar. Pertanyaan kelima tentang cara guru menyisipkan humor dalam pembelajaran disenangi oleh 
$76.84 \%$ siswa. Selanjutnya pertanyaan tentang jeda strategis yang diisi dengan sisipan humor dapat dinikamti oleh $77.90 \%$ siswa. Sebesar $79.99 \%$ siswa menyukai cara guru menyisipkan humor dalam pembelajaran. Sebanyak $81.07 \%$ siswa senang jika diberikan istirahat sejenak oleh guru dalam belajar matematika. Kemudian pada pertanyaan kesembilan diperoleh angka sebesar $77.88 \%$ siswa tidak merasa bosan belajar matematika dengan sisipan karikatur humor. Pertanyaan negatif tentang apakah siswa membenci guru yang mengajar matematika dengan selingan karikatur humor, $77.88 \%$ siswa menyatakan tidak (22,12\% menjawab ya). Pertanyaan kesebelas apakah siswa menginginkan semua guru menggunakan humor, $80.01 \%$ menginginkan ya. Pertanyaan terakhir apakah penyisipan karikatur humor oleh guru dapat membantu siswa mengingat pelajaran, sebesar $80.01 \%$ siswa menyatakan dapat membantu daya ingat. Berasarkan persentase rata-rata secara keseluruhan diperoleh angka 78,30\%.

Setelah dilaksanakan tindakan siklus 2 terjadi peningkatan. Sebanyak $86.33 \%$ siswa mengungkapkan bahwa karikatur yang ditayangkan mampu membuat pembelajaran menjadi menyenangkan. Capaian angka tersebut meningkat sebesar $5,22 \%$ dibandingkan persentase rata-rata pada siklus 1 sebesar $78,30 \%$. Peningkatan tersebut telah dapat meyakinkan peneliti bahwa indikator kinerja yang telah ditetapkan sebelumnya dapat dicapai. Peningkatan tersebut merupakan dari beberapa perbaikan dan penyempurnaan yang dilakukan berdasarkan refleksi kelemahan-kelemahan yang terjadi pada siklus 1 . 
c. Hasil Belajar

Hasil belajar diperoleh melalui tes esay yang diberikan oleh guru pada akhir tindakan pertama dan kedua. Skor hasil belajar rata-rata secara keseluruhan juga dijadikan indikator kinerja tindakan pada siklus 1 dan siklus 2. Perhitungan hasil belajar Matematika siswa mengungkapkan skor yang dicapai pada siklus 1 adalah 66,20 dan skor pada siklus 2 sebesar 71,89. Capaian tersebut menunjukkan peningkatan sebesar 5,69 poin $(6,70 \%)$. Berarti indikator kinerja kedua yang menjadi sasaran pelaksanaan strategi pembelajaran menyenangkan ini telah dapat dicapai dengan angka rata-rata sebesar 71,89

\section{Analisis Reflektif Siklus 1 dan Siklus 2}

Evaluasi terhadap capaian hasil yang diperoleh pada siklus 1 didasarkan pada dua hal yaitu tingkat kesenangan belajar dan hasil belajar. Hal ini terlihat dari persentase rata-rata siswa yang ketawa $77.60 \%$. Jika angka ini dikaitkan dengan pertanyaan apakah tayangan karikatur membuat siswa ketawa, $75.78 \%$ siswa menjawab ya. Terlihat bahwa antara perhitungan hasil observasi dan analisis jawaban siswa menggunakan angket ternyata tidak jauh berbeda. Berarti penayangan karikatur humor menunjukkan hasil belum optimal.

Indikator kinerja berikutnya adalah hasil belajar matematika yang dicapai siswa dalam siklus 1. Beradasarkan hasil belajar yang dicapai siswa hanya 66.20 , belum dapat memenuhi indikator kinerja yang ditetapkan sebesar 7,00 .Beradasarkan analisis terhadap kedua indikator yang telah diuraikan di atas, dapat disimpulkan bahwa kinerja pada sikus 1 belum dapat memenuhi capaian minimal, oleh karena itu penelitian ini perlu dilanjutkan pada siklus 2 . 
Sebelum melanjutkan pada siklus kedua, ada beberapa hal yang menjadi catatan peneliti baik positif maupun negatif. Catatan tentang dampak positif tersebut adalah sebagai berikut:

1) Optimalisasi jeda strategis yang diisi dengan sisipan humor melalui penayangan karikatur humor ternyata memberikan dampak positif terhadap kesenangan belajar, sehingga siswa tidak merasa bosan dalam mengikuti pelajaran.

2) Karikatur juga dapat membantu siswa dalam mengingat pelajaran, terutama gambar-gambar yang memiliki daya afirmatif tinggi. Siswa dapat mengaitkan informasi yang masuk ke otak memori dengan karikatur lucu, sehingga memudahkan siswa memanggil kembali jika dibutuhkan.

3) Suasana pembelajaran menyenangkan menggunakan sisipan karikatur humor berdampak positif juga terhadap guru yang mengajar dimana guru dapat memasuki segala situasi yang sedang dialami siswa dalam belajar. Bahkan dari angket terungkap bahwa sebagian besar siswa menginginkan semua guru menggunakan humor di dalam kelas.

Sedangkan catatan negatif atau kelemahan-kelemahan yang perlu disempurnakan pada siklus berikutnya adalah:

1) Jika guru tidak hati-hati menggunakan humor terutama dalam bentuk karikatur, maka kelas bisa mengalami kegaduhan akibat ketawa berlebihan yang susah dihentikan.

2) Jika guru tidak mampu mengendalikan siswa, maka konsentrasi siswa bisa pecah dari pelajaran yang dijelaskan pada sesi sebelumnya.

3) Siswa cenderung memancing guru untuk selalu bercanda, sehingga siswa lain menjadi terganggu.

a. Perenungan Berdasarkan Siklus Pertama 
Dari hasil refleksi pada siklus pertama, perlu dilakukan perbaikan pada siklus kedua sebagai berikut:

1) Cara guru menayangkan gambar karikatur humor dengan pengantar seadanya tanpa menyentuh dan terkait dengan materi yang sedang diajarkan, dampaknya gambar terlihat secara tiba-tiba tanpa masuk secara psikologis lebih awal sebelum penayangan. Pada siklus kedua dilakukan penyempurnaan dengan mengomentari materi yang telah diajarkan dan memberikan pengantar yang sedikit lucu sebelum menayangkan gambar karikatur humor.

2) Komentar yang diberikan guru sebelum dan setelah penayangan karikatur humor belum sepenuhnya dapat membuat siswa senang dalam belajar. Dari angket yang disebarkan kepada siswa masih ada sekitar $24,20 \%$ yang tidak senang dengan komentar guru. Oleh karena itu, pada siklus kedua diperbanyak komentar yang menyenangkan di dalam kelas.

3) Ada beberapa gambar karikatur humor yang menarik tapi tidak membuat siswa ketawa, karena hanya $75.78 \%$ siswa yang menyatakan bahwa penayangan karikatur humor tersebut dapat membuat mereka ketawa dan sisanya $24,22 \%$ tidak. Setelah ditelusuri lebih jauh, ternyata sebagian besar dari mereka menyatakan bahwa mereka tidak tertawa bukan semata-mata karena gambar karikaturnya tidak lucu, melainkan karena kualitas gambar (cetakan/fotokopi) kurang baik, kabur dan cacat transparansinya. Oleh karena itu, pada siklus kedua kualitas transparansi disempurnakan.

4) Sebesar 22, 10\% siswa tidak senang dengan sisipan karikatur humor saat jeda strategis. Melalui wawancara dengan siswa, terungkap bahwa 
sebagian siswa yang tidak senang ini menyatakan bahwa mereka merasa terganggu dengan adanya siswa yang bercanda berlebihan. Kelemahan tersebut diperbaiki dengan meningkatkan pengendalian situasi dan suasana kelas sehingga sebagian besar siswa dapat menikmati pembelajaran secara menyenangkan.

5) Meskipun pembelajaran menyenangkan telah dapat memberikan kontribusi yang relatif baik terhadap basil belajar, namun masih perlu sentuhan lain dalam membuat siswa dapat meningkatkan basil belajarnya. Salah satu cara yang telah dilakukan adalah dengan menyisipkan humor dalam pelaksanaan ujian. Pada siklus kedua sisipan humor yang tepat saat ujian disisipkan.

\section{b. Siklus Kedua}

Secara garis besarnya perencanaan dan pelaksanaan siklus kedua tidak jauh berbeda dari siklus pertama. Perbaikan yang dilakukan tidak merubah urutan pelaksanaannya, yang dilakukan hanyalah perubahan kebijakan yang dapat meningkatkan kesenangan belajar dan pada gilirannya meningkatkan basil belajar.

Jumlah siswa yang menikmati pembelajaran menyenangkan setelah tindakan dilakukan siklus 2 telah mencapai sasaran kinerja yang ditetapkan. Hal ini terlihat dari persentase rata-rata siswa yang ketawa 83.94\%. Jika angka ini dikaitkan dengan pertanyaan apakah tayangan karikatur membuat siswa ketawa, $86.33 \%$ siswa menjawab ya.

Berdasarkan indikator kinerja berikutnya yaitu basil belajar matematika yang dicapai siswa dalam siklus 2 , diperoleh angka 71.89, maka dapat disimpulkan bahwa tindakan pada siklus 2 telah memenuhi indikator kinerja 
yang ditetapkan sebelumnya yaitu 7,00. Dengan demikian, penelitian ini dilaksanakan sampai pada tindakan siklus 2 .

\section{B. Pembahasan}

Berdasarkan hasil yang dicapai pada siklus pertama, ada beberapa hal yang menjadi cacatan peneliti baik positif maupun negatif sebagai konsekuensi diterapkannya strategi pembelajaran ini. Beberapa catatan negatif yang belum teratasi pada siklus 1 , telah dilakukan perbaikan pada siklus 2 agar capaian hasil yang diperoleh lebih baik.

Upaya perbaikan terhadap optimalisasi jeda strategis yang diisi dengan sisipan humor melalui penayangan karikatur humor, kelihatan semakin baik dan semakin nyata hasilnya. Hal ini kelihatan dari meningkatnya angka indikator kinerja baik kesenangan belajar maupun hasil belajar Matematika yang dicapai siswa.

Peningkatan jumlah siswa yang tertawa setelah penayangan karikatur humor meningkat dari $77,60 \%$ menjadi $83.94 \%$ memberikan arti bahwa perbaikan yang telah dilakukan terhadap kelemahan yang ditemukan pada siklus 1 telah berhasil diperbaiki menjadi lebih baik. Indikasi persentase siswa yang ketawa dalam pembelajaran ini menjadi penting artinya dalam melihat tingkat kesenangan siswa dalam belajar. Semakin tinggi persentase siswa yang ketawa saat jeda strategis dilakukan, maka dapat diartikan semakin tinggi pula tingkat kesenangan belajar siswa. Semakin tinggi tingkat kesenangan belajar yang dicapai siswa, maka semakin tinggi pula keberhasilan optimalisasi jeda strategis dalam pembelajaran.

Penayangan gambar karikatur humor merupakan salah satu dari banyak cara untuk membuat siswa ketawa dalam upaya menciptakan Pembelajaran menyenangkan. 
Penelitian ini telah berhasil meningkatkan kesenangan belajar dalam mata pelajaran Matematika. Namun demikian, kemampuan guru untuk menerapkan strategi pembelajaran menyenangkan jauh lebih penting. Gambar karikatur humor yang paling lucu sekalipun, jika ditayangkan oleh guru yang suka pemarah, tidah ramah, kurang memiliki rasa humor yang memadai, maka siswa sulit diajak ketawa bersama di dalam kelas. Artinya strategi pembelajaran menyenangkan melalui optimalisasi jeda strategis tidak akan pernah berhasil tanpa didukung oleh kemampuan guru yang memadai.

Tingkat kesenangan belajar yang berhasil dicapai siswa juga diperkuat dengan hasil angket yang diberikan kepada siswa. Melalui 12 pertanyaan yang berkenaan dengan karikatur, pelaksanaan tindakan dan kesenangan belajar yang menjadi fokus dalam angket tersebut menunjukkan bahwa angka rata-rata secara keseluruhan melebihi $80 \%$. Hasil ini membuktikan bahwa observasi yang dilakukan guru dalam pembelajaran, memiliki tingkat keakuratan yang lebih baik, karena diperkuat hasil angket yang relatif sama.

Selanjutnya peningkatan yang terjadi dalam capaian hasil belajar Matematika siswa pada siklus 2 juga memperlihatkan bahwa perbaikan terhadap kebijakan pelaksanaan tindakan telah berhasil dengan baik. Hasil belajar Matematika yang dicapai siswa dengan angka ratarata 66,20 pada siklus I, meningkat menjadi 71,89 pada siklus 2. Kenaikan hasil belajar ini tentunya mengindikasikan bahwa pembelajaran dengan mengoptimalkan jeda strategis, selain menciptakann kesenangan belajar juga meningkatkan hasil belajar.

Apabila ditelusuri lebih jauh kenaikan capaian hasil belajar tersebut erat kaitannya dengan tingkat kesenangan belajar 
yang dialami siswa. Keberhasilan dalam meningkatkan capaian hasil belajar kemungkinan dipicu dan dipacu oleh Pembelajaran yang menyenangkan. Dugaan ini didasarkan pada beberapa alasan secara teoritis berikut.

Pertama, Pembelajaran menyenangkan telah memberikan stimulus yang sangat baik terhadap fungsi otak dalam memproses informasi. Stimulus yang menyenangkan dalam pembelajaran memungkinkan otak mamalia secara cepat meneruskan informasi ke otak neo korteks, sehingga ia dapat dengan cepat melaksanakan fungsinya sebagai pemroses informasi. Pemrosesan informasi oleh otak neo korteks inilah yang membuat keberhasilan belajar menjadi meningkat.

Kedua, keberhasilan memberikan stimulus yang menyenangkan dalam proses pembelajaran akan menghambat berfungsinya otak reptil yang sangat mengganggu siswa dalam belajar. Indikasi utama dari berfungsinya otak reptil adalah munculnya kejenuhan, kemarahan, ketidaksenangan, dan ketegangan dalam belajar. Suasana hati seperti itu, selain membuat siswa mengalami kesulitan dalam berpikir juga akan mempengaruhi siswa bertahan dengan kondisi prima untuk melaksanakan tugas-tugas pembelajaran. Belajar dengan tanpa gangguan psikologis seperti yang disebutkan di atas akan memberikan peluang kepada siswa untuk lebih berhasil. Dalam penelitian ini diduga kondisi tersebut memberikan sumbangan yang berarti terhadap peningkatan capaian hasil belajar.

Ketiga, stimulus yang menyenangkan juga mengaktifkan otak mamalia sebagai otak memori sekaligus juga otak emosi. Informasi yang masuk dengan melibatkan emosi akan tersimpan dalam otak memori dan informasi tersebut akan mudah diingat kembali ketika diperlukan. Kondisi 
seperti inilah yang dialami siswa saat mengikuti pembelajaran secara menyenangkan. Siswa yang berada dalam kondisi menyenangkan secara emosional, mudah menyimpan materi pelajaran dan memanggilnya kembali saat ujian. Kemudahan menyimpan informasi tentang materi pelajaran dan memanggil kembali dalam ujian inilah yang diduga mampu meningkatkan hasil belajar siswa.

Keempat, karikatur humor juga dapat membantu siswa dalam mengingat pelajaran, terutama gambar-gambar yang memiliki daya afirmatif cukup tinggi. Siswa dapat mengaitkan informasi yang masuk ke otak memori dengan cantolan karikatur humor, sehingga informasi tersebut dapat diingat dengan mudah saat diperlukan karena adanya keterlibatan emosi. Dengan demikian, dapat diartikan bahwa gambar karikatur lucu dapat dijadikan alat untuk meningkatkan kesenangan belajar dan cantolan dalam membantu daya ingat.

Berdasarkan uraian di atas dapat disimpulkan bahwa penelitian tindakan kelas dengan mengoptimalkan jeda strategis melalui penayangan gambar karikatur humor telah dapat memberikan sumbangan positif terhadap peningkatan Pembelajaran menyenangkan dan upaya meningkatkan hasil belajar. Meskipun demikian ada beberapa hal yang perlu dikembangkan melalui penelitian lebih lanjut antara lain tentang kecerdasan emosional guru dan siswa serta dampaknya terhadap proses pembelajaran yang menyenangkan. Pengembangan lebih lanjut dapat pula dilakukan pada sekolah-sekolah selain SMA bahkan perguruan tinggi. Hal ini sesuai dengan penelitian terakhir yang menyatakan bahwa belajar akan efektif kalau kita dalam keadaan gembira dan menyenangkan. 


\section{SIMPULAN DAN SARAN}

\section{A. Simpulan}

Berdasarkan hasil analisis data dan pembahasan dapat diambil beberapa simpulan sebagai berikut:

1. Penerapan strategi pembelajaran dalam upaya menciptakan Pembelajaran menyenangkan melalui optimalisasi jeda strategis dengan karikatur humor ini telah berhasil meningkatkan kesenangan siswa dalam belajar. Keberhasilan tersebut dapat dilihat dari hasil analisis terhadap reaksi siswa selama jeda strategis dilaksanakan melalui observasi langsung oleh kolaborator maupun hasil analisis angket yang diberikan kepada siswa.

2. Hasil penelitian ini juga mengungkapkan bahwa strategi pembelajaran menyenangkan menggunakan karikatur humor selain dapat meciptakan Pembelajaran menyenangkan, juga mampu membantu meningkatkan hasil belajar Matematika siswa.

3. Berdasarkan uraian di atas, dapat pula diambil kesimpulan akhir dari penelitian ini bahwa strategi pembelajaran menyenangkan melalui optimalisasi jeda strategis ini dapat digunakan dalam upaya meningkatkan kesenangan belajar dan pada gilirannya membantu siswa dalam mencapai hasil belajar lebih optimal.

\section{B. Saran}

Berdasarkan pembahasan, refleksi dan kesimpulan di atas dapat diberikan sara-saran sebagai berikut:

1. Disarankan kepada para guru untuk mencoba cara-cara yang diterapkan dalam penelitian ini pada bidang studi lain dengan berbagai variasinya melalui penelitian maupun dalam praktek pembelajaran di dalam kelas.

2. Penelitian ini hanya terbatas optimalisasi jeda strategis melalui sisipan karikatur humor. Disarankan untuk menggali lebih dalam melalui penelitian lanjutan dengan cara-cara dan teknik lain seperti musik, kuiz dan sebagainya. 
3. Penelitian ini telah berhasil dilaksanakan dengan objek siswa SMA, tetapi untuk pengembangan lebih jauh disarankan untuk melakukan penelitian lanjutan pada level pendidikan SMP dan SD atau perguruan tinggi.

4. Guru yang melaksanakan strategi ini disarankan untuk berhati-hati dan dapat mengendalikan kelas, agar tidak menimbulkan kegaduhan akibat adanya siswa tertawa berlebihan tidak terkendali, sehingga mengganggu siswa lainnya dalam belajar.

\section{DAFTAR PUSTAKA}

Berk, R.A. 1998. "Student Rating of 10 Strategies for Using Humor in College Teaching. "Journal of Excellece in College Teaching, 7, 71-92. Brotherton, P. 1996. "The Company that Play Together". HR Magazine, 41, 76-83.

DePorter, Bobbi.,Reardon Mark.,Singer-Nouri, Sarah.1999. Quantum Teaching. Terjemahan Ary Nilandari. Bandung: Kaifa.

Dhoroty, Lynn. 1991. The ACT Aproach: The Artful Use of Suggestion for Integrative Learning. Bremen. Germany: PLS Verlag.

Dinas Pendidikan Sumbar.2003. Profil Pendidikan Sumatera Barat .

Padang: Proyek PTP - Sumatera Barat.

Dryden, Gordon dan Vos, Jeannette. 2000. Revolusi Cara Belajar. Jakarta : Penerbit Kaifa.

Dryden, Gordon dan Vos, Jeannette. 2000. Revolusi Cara Belajar. Jakarta : Penerbit Kaifa.

Flowers,J. 2001. "The Value of Humour in Technology Education" Technology Teacher, 60, 10-13.

Friedmen, H., Hersyey, Friedmen, W., Linda, and Amoo, Taiwo. 2002. "Using Humor in the Introductory Statictcs Couse". City Univerisity of New York Journal of Statistics Education, 10 (3), 1- 13.

Gagne M., Robert. 1986. The Conditions of Learning and Theory of Instruction. Tokyo : Holt-Saunders Japan.

Herman Nirwana .2003. "Hubungan Tingkat Aspirasi dan Persepsi tentang Belajar dengan Hasil Belajar Matematika Siswa Sekolah 
Menengah Umum yang Berlatar Belakang Budaya Minangkabau dan Batak". Disertasi tidak diterbitkan. Malang: Program Pascasarjana Universitas Negeri Malang.

James Danandjaya. 1999. Humor dan Rumor Politik Masa Reformasi. Depok: Permata Ad.

Reigeluth, Charles, M. 1983. Instructional Design Theories and Model. New Jersey: Lawrence Erlbaum Associates.

Romiszowski, A., J., 1986. Producing Instructional System. London: Kogan Page.

Shapiro, E. Lawrence.1997. Mengajarkan "Emotional Inteligent" pada Anak. Jakarta: PT. Gramedia Pustaka Utama.

Shor, Ira \& Freire, Paulo. 2001. Menjadi Guru Merdeka. Yogyakarta: LKiS

Staton, F. Thomas. 1992. Cara Mengajar dengan Hasil yang Baik. (Metode-metode Mengajar Modern dalam Pendidikan Orang Dewasa)- Terjemahan Prof.J.F. Tahalele, M.A. Bandung: Cv. Diponegoro.

Syaiful Bahri Djamarah. (1994).Prestasi Belajar dan Kompetensi Guru. Surabaya: Usaha Nasional.

Travers, M.Robert.1982. Essentials of Learning. New York: Macmillan Publishing Co.Inc. 